\title{
RELIGIJNOŚĆ I ZACHOWANIA ZDROWOTNE PACJENTÓW Z DEPRESJA
}

\section{RELIGIOUSNESS AND HEALTH BEHAVIORS OF PATIENTS WITH DEPRESSION}

\author{
Agata Sikora ${ }^{1, a}$, Anna Majda ${ }^{2, b}$, Anna Kurowska ${ }^{2, c}$ \\ ${ }^{1}$ V Wojskowy Szpital Kliniczny z Polikliniką w Krakowie \\ ${ }^{2}$ Wydział Nauk o Zdrowiu, Uniwersytet Jagielloński Collegium Medicum w Krakowie \\ ${ }^{\text {a }}$ https://orcid.org/0000-0003-2461-5280 \\ ${ }^{\mathrm{b}}$ https://orcid.org/0000-0003-3632-1319 \\ ${ }^{c}$ https://orcid.org/0000-0002-2937-5346
}

DOI: https://doi.org/10.20883/pielpol.2021.1

\section{STRESZCZENIE}

Wstęp. W ostatnich latach można dostrzec wzrost zainteresowania tematyką religijności oraz wpływem religii na zdrowie. Uwzględnienie przekonań religijnych jest ważnym, choć często rzadko dostrzeganym, elementem podczas świadczenia opieki pielęgniarskiej.

Cel. Celem pracy była ocena stopnia religijności oraz zachowań zdrowotnych pacjentów chorych na depresję oraz zbadanie korelacji między nimi.

Materiał i metody. W badaniu wzięło udział 104 pacjentów chorujących na depresję. Zachowania zdrowotne grupy badanej zostały określone za pomocą autorskiego kwestionariusza, natomiast stopień religijności oceniono na podstawie Skali Indywidualnej Religijności autorstwa A. Latały i P. Sochy.

Wyniki. Badani pacjenci z depresją cechowali się znacznym stopniem religijności. Zachowaniami zdrowotnymi, najczęściej przestrzeganymi przez badanych, było przyjmowanie leków, spożywanie warzyw i owoców oraz produktów bogatych w kwas omega-3. Wyższą religijnością cechowały się osoby starsze, mieszkające na wsi, a także osoby z wykształceniem średnim, podstawowym i zawodowym. Wyższym poziomem zachowań zdrowotnych charakteryzowały się osoby z wykształceniem wyższym oraz aktywne zawodowo. Badani częściej modlący się indywidualnie oraz uczestniczący w mszach niedzielnych rzadziej byli hospitalizowani z powodu depresji.

Wnioski. Nie zaobserwowano istotnej zależności pomiędzy poziomem religijności pacjentów $z$ depresją a poziomem przejawianych przez nich zachowań zdrowotnych.

SŁOWA KLUCZOWE: depresja, religijność, zachowania zdrowotne, zdrowie.

\section{Wprowadzenie}

Współcześnie religię definiuje się jako zespół wierzeń dotyczących istnienia Boga lub bogów, pochodzenia i celu życia człowieka, powstania świata oraz związane z nimi obrzędy, zasady moralne i formy or-

\begin{abstract}
Introduction. In recent years, a growing interest in the subject of religiousness and the influence of religion on health can be noticed. Considering religious beliefs is an important element, although often not very noticeable while providing nursing care. Aim. The aim of this study was to assess the religiousness and health behaviours of patients with depression and to investigate the correlation between them.

Material and methods. The group of 104 patients suffering from depression participated in the study. Health behaviours of the study group were determined using the author's questionnaire, while the degree of religiousness was assessed on the basis of the Individual Religiosity Scale by A. Latała and P. Socha.

Results. The study participants with depression were characterized by a significant degree of religiousness. Health behaviours such as taking medications, eating fruit, vegetables and products rich in omega-3 acid were the most often observed by the respondents. The higher degree of religiousness was observed in the elderly, countryside inhabitants, as well as people with secondary, basic and vocational education. The higher level of health behaviours was characteristic for people with higher education level and professionally active. The respondents who prayed more often individually and participated in Sunday Masses were less likely to be hospitalized due to depression.

Conclusions. There was no significant correlation between the level of religiousness of patients with depression and the level of health behaviours manifested by them.
\end{abstract}

KEYWORDS: depression, religiousness, health behaviours, health.

ganizacyjne [1]. Religijność rozumiana jest jako stopień zaangażowania jednostki w wiarę i praktyki religijne. Jest ona różnicowana ze względu na tradycje panujące $\mathrm{w}$ danej religii. Może opierać się na podejmowaniu praktyk wspólnotowych bądź też na indywidualnej re- 
lacji z Bogiem. Religijność katolików opiera się na połączeniu życia wspólnotowego z osobistą modlitwą. Termin ten jest niejednokrotnie stosowany wymiennie z duchowością. Polska tradycja jednak różnicuje te pojęcia [2]. Duchowość rozumiana jest jako proces poszukiwania sacrum i życiowych wartości. Doprowadza on do przekształcania zachowań jednostki oraz ciągłego życia według nowych zasad. Duchowość może również być postrzegana jako osobiste doświadczenie sacrum i towarzyszące temu emocje [3]. Podejście psychologiczne do religijności opiera się w dużej mierze na subiektywnym odczuwaniu przez jednostkę. Pierwszym z ważnych elementów religijności jest wiedza jaką osoba posiada na temat tradycji religijnych, sposobu okazywania szacunku i czci dla uznawanego przez siebie bóstwa. W podejściu psychologicznym zwraca się również uwagę na przekonania, preferowane wartości oraz stosunek osoby do symboli religijnych, mitów, wierzeń ludowych i obyczajów [4]. Elementem religijności jest akt wiary czy też wiara. Zgodnie z definicją wiara to „osobowy, świadomy i wolny akt ludzki (akt rozumu i woli) afirmujący istnienie Boga, Istoty Najwyższej, absolutu lub sił nadnaturalnych; w teologii chrześcijańskiej jest, oprócz nadziei i miłości, jedną z cnót teologicznych" [4]. Dodatkowymi elementami religijności są także zachowania religijne, czynności wykonywane indywidualnie jak i grupowo. Mogą również pojawić się dodatkowe doświadczenia obecności czy też działania sił nadnaturalnych. Ostatnim wyróżnianym element religijności jest wymiar konsekwencyjny. W takim podejściu zwraca się uwagę na wpływ religijności na życie moralne jednostki [4].

Zgodnie z przedstawionymi rozważaniami „religijność to złożona, zawierająca między innymi element wiary rozumnej jako akt wierzenia, wielowymiarowa struktura, zorganizowana jako dynamiczny, powiązany z innymi systemami psychologicznymi (takimi jak motywacja, osobowość) i wpływający na funkcjonowanie podmiotu, system poznawczy. System ten przetwarza niedające się dowieść treści, lecz które w danym kulturowym środowisku mają status jako religijna tradycja" [4]. Tak skonstruowana definicja zwraca uwagę zarówno na konsekwencje wewnętrzne, jak i zewnętrzne wynikające z faktu bycia religijnym. Są to między innymi: zmiany w hierarchii celów i wyznawanych wartości czy zmiana w osobowości. Takie postępowanie nie musi być świadomym wynikiem analizy rzeczywistości lub biegu zdarzeń. Często jest to nieuświadomione postępowanie [4].

Na zachowania zdrowotne duży wpływ ma kontekst kulturowy, do którego zalicza się religię. Religia oprócz zwracania uwagi na Boską Istotę podkreśla znaczenie ludzkiego życia i zdrowia. Jest to również wartość, która regulowana jest wieloma przepisami religijnymi. $\mathrm{Na}$ straży zdrowia stoi wiele nakazów i zakazów. Dotyczą one zarówno funkcjonowania społecznego, jak i zachowań zdrowotnych. Są to między innymi wskazania dotyczące postów, sposobu odżywiania się, odpoczynku, higieny. Przepisy religijne dotyczą również stosunku człowieka do własnego ciała. Nadużywanie używek, a co za tym idzie niszczenie własnego ciała, jest uznawane za grzech $[5,6]$. Aktywności jakie podejmuje człowiek w wyniku przekonań religijnych możemy podzielić na takie, które mają obojętny, pozytywny lub negatywny wpływ na zdrowie. Do pierwszej grupy należą rytualne obmycia w świętej wodzie. Stosowane są one w wielu religiach. $W$ hinduizmie są to obmycia w rzece Ganges. Muzułmanie wykorzystują w tym celu wodę ze świętej studni w Makka. Również w religii chrześcijańskiej stosuje się wodę z Lourdes. Zachowania takie mają dać poczucie wsparcia w cierpieniu i pomóc w powrocie do zdrowia [6]. Jako pozytywne aktywności uznaje się podejmowanie wysiłku fizycznego. W wielu religiach są to np. pielgrzymki do miejsc świętych. Taki kilkugodzinny, a nawet kilkudniowy wysiłek uważany jest za sprzyjający zdrowiu. Dodatkowym elementem w podejmowaniu takich praktyk jest obecność osób o podobnych poglądach. Daje to jednostce poczucie przynależności do grupy społecznej. Jest to czynnik działający korzystnie na ludzką psychikę [5, 6]. Podobnie sposób odżywiania uwarunkowany poglądami religijnymi może sprzyjać zdrowiu. Przykładem może być spożywanie posiłków z wyłączeniem mięsa wieprzowego, natomiast z większą ilością produktów roślinnych. Dodatkowo niektóre nakazy religijne zabraniają spożywania posiłków w godzinach nocnych [6]. Praktyki postów rozpowszechnione są również w wielu religiach. Występują one przede wszystkim w islamie i Kościele katolickim. Są to zachowania, które sprzyjają zdrowiu. Oczywiście nadmierny post „o chlebie i wodzie” jest bardzo niekorzystny dla człowieka. Może on w ekstremalnych przypadkach doprowadzić do wycieńczenia organizmu, a nawet do śmierci [6]. Religia może mieć również wpływ na profilaktykę uzależnień. Większość religii zaleca swoim wyznawcom wstrzemięźliwość od używek, tj. alkoholu, nikotyny i narkotyków. Niekiedy nawet zakazane jest stosowanie takich środków. W Kościele katolickim szczególny nacisk kładzie się na abstynencję dzieci i młodzieży. Osoby dorosłe wezwane są do nienadużywania środków psychoaktywnych. Odłamy i ruchy niektórych religii składają przyrzeczenia o dozgonnej abstynencji [6]. Religia, jak i podejmowane praktyki religijne mają duże znaczenie $\mathrm{w}$ radzeniu sobie ze stresem. W modlitwie i innych praktykach religijnych można odnaleźć siłę do rozwiązania problemów. Często religia może dać poczucie sensu, nawet w obliczu trudnych sytuacji. Cennym jest również poczucie wsparcia psychicznego, duchowego i materialnego otrzymanego od wspólnoty [5]. 


\section{Cel pracy}

Celem pracy była ocena religijności i zachowań zdrowotnych wśród pacjentów chorych na depresję oraz zbadanie korelacji między tymi zmiennymi. W oparciu o analizę piśmiennictwa sformułowano następujące problemy badawcze:

1. Jakie zachowania zdrowotne prezentują pacjenci z depresją?

2. Jakie jest zaangażowanie religijne pacjentów z depresją?

3. Jaki jest stopień religijności pacjentów z depresją?

4. Czy istnieje zależność między religijnością a zachowaniami zdrowotnymi pacjentów z depresją?

5. Czy religijność pacjentów z depresją zależy od zmiennych socjodemograficznych?

6. Czy zachowania zdrowotne pacjentów z depresją zależą od zmiennych socjodemograficznych?

7. Czy podejmowane praktyki religijne przez pacjentów z depresją sprzyjają zdrowiu psychicznemu?

8. Czy podejmowane przez pacjentów z depresją zachowania zdrowotne sprzyjają zdrowiu psychicznemu?

\section{Materiał i metody}

Badania zostały przeprowadzone na oddziale psychiatrycznym jednego ze szpitali klinicznych w Krakowie, zgodnie z wymogami Deklaracji Helsińskiej (2013) [7]. Trwały od października 2018 roku do kwietnia 2019 roku. Na ich przeprowadzenie uzyskano zgodę dyrekcji szpitala oraz ordynatorów poszczególnych oddziałów. Przed przystąpieniem do wypełnienia narzędzi badawczych każdy pacjent został poinformowany o celu badania oraz o jego dobrowolności. Do badań przystąpiło 104 pacjentów z rozpoznaną na podstawie dokumentacji medycznej depresją. Kolejnym warunkiem przystąpienia do badania był wiek pacjentów. Ankietowani byli osobami pełnoletnimi, lecz ich wiek nie przekraczał 65 lat. Każdy z nich zadeklarował, że jest osobą wierzącą, wyznania rzymsko-katolickiego. Średni czas, jaki pacjenci poświęcali na wypełnienie ankiety, wynosił ok. 20 minut. Zdecydowana większość pacjentów wypełniała ankiety samodzielnie. W przypadku wątpliwości pacjenci mogli zadawać pytania autorom badania, obecnym podczas wypełniania narzędzi badawczych. Wszystkie zebrane narzędzia badawcze wypełnione zostały w całości poprawnie.

W celu przeprowadzenia badań posłużono się dwoma metodami, tj. metodą sondażu diagnostycznego i metodą szacowania. Wykorzystano technikę ankietową i technikę skalowania. Osoby badane wypełniały dwa narzędzia badawcze. Pierwszym z nich był autorski kwestionariusz ankiety. Składał się on z trzech części dotyczących: zachowań zdrowotnych - 17 pytań; zaangażowania religijnego - 11 pytań; zmiennych socjodemograficznych - 12 pytań. W pytaniach dotyczących zachowań zdrowotnych odpowiedzi zostały oznaczone liczbowo, zgodnie z częstotliwością podejmowanych zachowań. Liczba 1 oznaczała, że pacjent „nigdy” nie podejmował danego działania, a cyfra 6 , że „kilka razy dziennie". W pozostałych pytaniach pacjenci zaznaczali jedną odpowiedź z podanych wariantów. Drugim narzędziem była Skala Indywidualnej Religijności (SIR) autorstwa A. Latały i P. Sochy. Skala Indywidualnej Religijności powstała w celu badania postaw wobec religii katolickiej. Skala obejmowała cztery składniki religijności, takie jak.: doktryna religijna, moralność religijna, stosunek do Kościoła katolickiego oraz kult religijny. W skali tej osoby badane uzyskać mogły od 24 do 120 pkt. Większa liczba uzyskanych punktów świadczyła o wyższym stopniu religijności badanej jednostki [8].

Analizę statystyczną zebranego materiału badawczego wykonano w programie Statistica 13.1 firmy StatSoft. W badaniu posłużono się testami nieparametrycznymi, gdyż wybór testów parametrycznych uwarunkowany był spełnieniem założenia normalności rozkładów badanych zmiennych, którego w niniejszej pracy nie spełniono. Do oceny różnic w wynikach uzyskanych w dwóch grupach zastosowano test U MannaWhitneya. Obecność związków pomiędzy zmiennymi określonymi co najmniej na skali porządkowej oceniono za pomocą testu korelacji rang Spearmana (r). Za poziom istotności statystycznej przyjęto $p<0,05$.

\section{Wyniki}

W badaniu udział wzięło 104 pacjentów chorujących na depresję. W badanej grupie było $66(63,5 \%)$ kobiet i 38 (36,5\%) mężczyzn. Badani byli w wieku od 20 do 64 lat. Średnia wieku badanych wynosiła 43,32 \pm 14,11 roku. W badanej grupie na podstawie wyników BMI, było $60(57,7 \%)$ osób mających prawidłową masę ciała, 36 $(34,6 \%)$ osób z nadwagą oraz $8(7,7 \%)$ osób otyłych. Wśród badanych było 45 (43,2\%) osób mieszkających na wsi, 16 (15,4\%) osób zamieszkujących małe miasta, 11 (10,6\%) osób zamieszkujących miasta średniej wielkości oraz $32(30,8 \%)$ osoby zamieszkujące duże miasta. Najwięcej badanych miało wykształcenie wyższe - 47 $(45,2 \%)$ osób. Wykształcenie średnie miało 27 (26,0\%) badanych, wykształcenie zawodowe - 18 (17,3\%) osób oraz wykształcenie podstawowe - 12 (11,5\%) osób. Badaną grupę stanowiło 44 (42,3\%) osoby stanu wolnego oraz $7(6,7 \%)$ osób owdowiałych. Osób w związkach małżeńskich było 53 (51,0\%). Najliczniejszą grupę badanych stanowiły osoby aktywne zawodowo - $49(47,1 \%)$ osób. Osób będących na rencie lub emeryturze było 30 (28,9\%), bezrobotnych - 20 (19,2\%), natomiast studiu- 
jących - 5 (4,8\%) osób. Wszyscy badani uważali się za osoby wierzące i byli wyznania rzymsko-katolickiego. $\mathrm{Na}$ depresję badani chorowali od miesiąca do 37 lat. Średni okres trwania choroby wynosił w badanej grupie około 8 lat (7,68 roku). Połowa badanych chorowała nie dłużej niż 4 lata, lecz co czwarty badany, chorował nie krócej niż 10 lat.

W ciągu ostatniego roku, poprzedzającego badanie, respondenci hospitalizowani byli z powodu depresji najczęściej jednokrotnie - 83 (79,8\%) osoby. Dwie hospitalizacje z tego powodu odbyło 19 (18,3\%) badanych, natomiast trzy - 2 (1,9\%) osoby. Obecność innych chorób przewlekłych, poza depresją, stwierdzono u 36 (34,6\%) badanych. Chorobami zdiagnozowanymi u respondentów były m.in.: cukrzyca typu II, nadciśnienie tętnicze, alergia, niedoczynność tarczycy, przepuklina kręgosłupa, zwyrodnienie kręgosłupa, zwyrodnienie stawów, astma oskrzelowa, nadczynność tarczycy, przewlekła obturacyjna choroba płuc oraz alkoholizm.

\section{Analiza zachowań zdrowotnych w grupie badanej}

Zachowania zdrowotne najczęściej przestrzegane przez badanych to przyjmowanie zalecanych przez lekarza leków, spożywanie warzyw i owoców oraz produktów bogatych w kwas omega-3. Badani stosunkowo często wskazywali także na otrzymywanie pomocy od osób bliskich. Z kolei zachowania antyzdrowotne prezentowane przez badanych to najczęściej spożywanie cukrów prostych i skrobi, narażenie na stres, miewanie uczucia grzeszności i wyrzutów sumienia oraz poczucia izolacji społecznej, osamotnienia (Tabela 1).

Poziom zachowań zdrowotnych badanych osób określono w skali od 18 do 108 pkt. Badani w każdej z kategorii uzyskać mogli od 1 do 6 pkt., a zawsze wyższa liczba punktów oznaczała większe nasilenie zachowań zdrowotnych (mniejsze nasilenie zachowań antyzdrowotnych). Ogólny poziom zachowań zdrowotnych badanych osób oceniono średnio na około 62 pkt. na 108 możliwych, co stanowiło 57,0\%. Najniższą uzyskaną punktacją było 45,0 pkt., zaś najwyższą 75,0 pkt. Poziom zachowań zdrowotnych badanych znajdował się na średnim poziomie w przyjętej skali.

Tabela 1. Prezentowane przez badanych zachowania zdrowotne Table 1. Health behaviours presented by the respondents

\begin{tabular}{|c|c|c|c|c|c|c|c|}
\hline $\begin{array}{l}\text { Częstość wybranych zachowań zdrowotnych/ antyzdrowotnych/Frequ- } \\
\text { ency of selected health /anti-health behaviors }\end{array}$ & $\begin{array}{c}\text { Nigdy/ } \\
\text { Never } \\
\mathrm{n} / \% \\
\end{array}$ & $\begin{array}{c}1 \mathrm{x} / \text { tyg. } /< \\
1 \mathrm{x} / \text { week } \\
\mathrm{n} / \%\end{array}$ & $\begin{array}{c}\text { 1x/tyg./ } 1 \mathrm{x} / \\
\text { week } \\
\mathrm{n} / \%\end{array}$ & $\begin{array}{c}2 \mathrm{x} / \text { tyg./ } 2 \mathrm{x} / \\
\text { week } \\
\mathrm{n} / \%\end{array}$ & $\begin{array}{c}\text { Codziennie/ } \\
\text { Every day } \\
\mathrm{n} / \% \\
\end{array}$ & $\begin{array}{c}\text { Kilka razy dziennie/ } \\
\text { Several times a day } \\
n / \%\end{array}$ & $\bar{x}$ \\
\hline $\begin{array}{l}\text { Przyjmowanie zaleconych przez lekarza leków/Taking medication } \\
\text { recommended by a doctor }\end{array}$ & $0 / 0,0$ & $4 / 3,8$ & $2 / 1,9$ & $0 / 0,0$ & $32 / 30,8$ & $66 / 63,5$ & 5,48 \\
\hline $\begin{array}{l}\text { Stosowanie preparatów witaminowo mineralnych/The use of vitamin and } \\
\text { mineral preparations }\end{array}$ & $21 / 20,2$ & $19 / 18,3$ & $22 / 21,2$ & $15 / 14,4$ & $27 / 26,0$ & $0 / 0,0$ & 3,08 \\
\hline $\begin{array}{l}\text { Suplementowanie wit. D3 w okresie jesieni i zimy/Supplementation of } \\
\text { vitamin D3 in autumn and winter }\end{array}$ & $55 / 52,9$ & $28 / 26,9$ & $8 / 7,7$ & $2 / 1,9$ & $11 / 10,6$ & $0 / 0,0$ & 1,90 \\
\hline Stosowanie ziół antydepresyjnych/The use of anti-depressant herbs & $59 / 56,7$ & $18 / 17,3$ & $10 / 9,6$ & $4 / 3,8$ & $13 / 12,5$ & $0 / 0,0$ & 1,98 \\
\hline Spożywanie warzyw i owoców/Eating vegetables and fruits & $0 / 0,0$ & $3 / 2,9$ & $6 / 5,8$ & $28 / 26,9$ & $36 / 34,6$ & $31 / 29,8$ & 4,83 \\
\hline $\begin{array}{l}\text { Spożywanie cukrów prostych i skrobi/Consumption of simple sugars } \\
\text { and starch }\end{array}$ & $2 / 1,9$ & $5 / 4,8$ & $6 / 5,8$ & $21 / 20,2$ & $48 / 46,2$ & $22 / 21,2$ & 4,67 \\
\hline $\begin{array}{l}\text { Spożywanie produktów bogatych w kwas omega- } 3 \text { / Consuming foods } \\
\text { rich in omega-3 acid }\end{array}$ & $2 / 1,9$ & $27 / 26,0$ & $20 / 19,2$ & $27 / 26,0$ & $24 / 23,1$ & $4 / 3,8$ & 3,54 \\
\hline $\begin{array}{l}\text { Spożywanie produktów bogatych w wit. B/Consumption of products } \\
\text { rich in vit. B }\end{array}$ & $5 / 4,8$ & $32 / 30,8$ & $19 / 18,3$ & $32 / 30,8$ & $12 / 11,5$ & $4 / 3,8$ & 3,25 \\
\hline Spożywanie alkoholu/Alcohol consumption & $43 / 41,3$ & $39 / 37,5$ & $10 / 9,6$ & $11 / 10,6$ & $0 / 0,0$ & $1 / 1,0$ & 1,93 \\
\hline Zażywanie narkotyków/Taking drugs & $97 / 93,3$ & $7 / 6,7$ & $0 / 0,0$ & $0 / 0,0$ & $0 / 0,0$ & $0 / 0,0$ & 1,07 \\
\hline Stosowanie produktów nikotynowych/Use of nicotine products & $72 / 69,2$ & $3 / 2,9$ & $2 / 1,9$ & $0 / 0,0$ & $6 / 5,8$ & $21 / 20,2$ & 2,31 \\
\hline $\begin{array}{l}\text { Podejmowanie form aktywności fizycznej/Undertaking forms of physical } \\
\text { activity }\end{array}$ & $7 / 6,7$ & $21 / 20,2$ & $24 / 23,1$ & $29 / 27,9$ & $20 / 19,2$ & $3 / 2,9$ & 3,41 \\
\hline Częstość bycia narażonym na stres/Frequency of being exposed to stress & $0 / 0,0$ & $7 / 6,7$ & $21 / 20,2$ & $19 / 18,3$ & $45 / 43,3$ & $12 / 11,5$ & 4,33 \\
\hline $\begin{array}{l}\text { Częstość otrzymywania wsparcia od bliskich/ Frequency of receiving } \\
\text { support from loved ones }\end{array}$ & $11 / 10,6$ & $9 / 8,7$ & $8 / 7,7$ & $13 / 12,5$ & $50 / 48,1$ & $13 / 12,5$ & 4,16 \\
\hline $\begin{array}{l}\text { Częstość spotykania się ze znajomymi/przyjaciółmi/Frequency of } \\
\text { meeting friends }\end{array}$ & $16 / 15,4$ & $43 / 41,3$ & $25 / 24,0$ & $5 / 4,8$ & $10 / 9,6$ & $5 / 4,8$ & 2,66 \\
\hline $\begin{array}{l}\text { Częstość poczucia izolacji społecznej, osamotnienia/Frequency of } \\
\text { social isolation, Ioneliness }\end{array}$ & $16 / 15,4$ & $22 / 21,2$ & $12 / 11,5$ & $19 / 18,3$ & $18 / 17,3$ & $17 / 16,3$ & 3,50 \\
\hline $\begin{array}{l}\text { Miewanie wyrzutów sumienia, uczucia grzeszności/ Feeling guilty, } \\
\text { feelings of sinfulness }\end{array}$ & $10 / 9,6$ & $23 / 22,1$ & $23 / 22,1$ & $13 / 12,5$ & $19 / 18,3$ & $16 / 15,4$ & 3,54 \\
\hline
\end{tabular}

$\mathrm{n}$ - liczba osób/sample size; \% - procent/the percentage of the investigated group; $\bar{x}$ - średnia arytmetyczna/mean,

Źródło: opracowanie własne

Source: author's own analysis 


\section{Analiza zaangażowania religijnego w grupie badanej}

Badani uczestniczyli w niedzielnych mszach świętych zazwyczaj w każdą niedzielę - 65 (62,5\%) osób. Trzy razy w miesiącu brało w niej udział - 11 (10,6\%) osób, a dwa razy w miesiącu - 19 (18,3\%) osób. Sporadycznie, tylko w duże święta, w mszach uczestniczyło - 9 $(8,6 \%)$ badanych. Respondenci rzadko uczestniczyli $w$ mszach świętych $w$ dni powszednie. Kilka razy w tygodniu uczestniczyło w nich - 16 (15,4\%) badanych, raz w tygodniu - 14 (13,5\%) badanych oraz raz w miesiącu - $15(14,4 \%)$ badanych. Kilka razy w roku w nabożeństwach uczestniczyło - 30 (28,8\%) badanych, natomiast 29 (27,9\%) badanych nie uczestniczyło w nich wcale. Respondenci przystępowali do spowiedzi świętej najczęściej kilka razy w roku - 43 (41,3\%) osoby, a nierzadko także raz $\mathrm{w}$ roku (w okresie wielkanocnym) - 25 (24,0\%) osób. Komunia święta przyjmowana była przez badanych najczęściej tylko w święta - $42(40,4 \%)$ osoby lub kilka razy w miesiącu - $37(35,6 \%)$ osób. Nie przystępowało do komunii - $6(5,8 \%)$ badanych, natomiast codziennie przyjmowały ją $2(1,9 \%)$ osoby. Najwięcej badanych modliło się indywidualnie dwa razy dziennie - $28(26,9 \%)$ osób lub kilka razy dziennie $26(25,0 \%)$ osób. Średnio co dziesiąty respondent nie modlił się indywidualnie. Pismo święte czy inną prasę religijną czytało - 52 (50,0\%) badanych. Ankietowani w większości byli przywiązani do tradycji Kościoła katolickiego i przyjmowali ją w całości - 67 (64,4\%) osób, lecz spora część badanych - 16 (15,4\%) osób, pomimo przywiązania do tradycji Kościoła, uznawała ją za nieaktualną. Dla $37(35,6 \%)$ badanych religia i religijność były bardzo ważnym elementem w procesie zdrowienia. W opinii $28(26,9 \%)$ ankietowanych były one pomocne, $26(25,0 \%)$ badanych nie dostrzegało wpływu religii czy religijności na proces zdrowienia, natomiast 13 (12,5\%) osób uznawało, że sprzyja ona dolegliwościom chorobowym. Przynależność do organizacji religijnej, wspólnoty modlitewnej lub inny sposób zaangażowania w życie wspólnoty parafialnej zadeklarowało 28 (26,9\%) badanych. Grupa 56 (53,8\%) ankietowanych uznawała siebie za osoby niezaangażowane w życie wspólnoty parafialnej. Słabo zaangażowanych było 28 (26,9\%) osób, średnio zaangażowanych było 16 (15,4\%) badanych, natomiast bardzo zaangażowane były 4 (3,9\%) osoby.

\section{Analiza religijności badanych przy użyciu Skali Indywidualnej Religijności}

Na podstawie Skali Indywidualnej Religijności określono stopień religijności badanych osób chorujących na depresję. Stopień religijności respondentów określono na średnim poziomie około 93 pkt. w skali 120 punktowej $(77,5 \%)$. Połowa badanych uzyskała nie mniej niż
99 pkt. w skali, zaś co czwarty badany uzyskał ich nie mniej niż 112. Badani pacjenci z depresją charakteryzowali się znacznym stopniem religijności.

W badaniu nie stwierdzono istotnej statystycznie zależności pomiędzy stopniem religijności badanych osób a prezentowanymi przez nich zachowaniami zdrowotny$\mathrm{mi}(R=0,07 ; p=0,461)$. Stopień religijności badanych pacjentów związany był z ich miejscem zamieszkania $(p<0,001)$ i wykształceniem $(p<0,001)$. Bardziej religijne były osoby mieszkające na wsi niż w mieście, a także osoby z wykształceniem średnim, podstawowym i zawodowym w porównaniu do osób z wykształceniem wyższym. Stopień religijności badanych osób nie był natomiast związany $z$ ich płcią, stanem cywilnym oraz statusem zawodowym (Tabela 2).

Tabela 2. Ocena stopnia religijności badanych w zależności od wybranych zmiennych socjodemograficznych

Table 2. Assessment of degree of religiousness depending on selected sociodemographic variables in a group of respondents

\begin{tabular}{|c|c|c|c|c|}
\hline $\begin{array}{l}\text { Zmienna/ } \\
\text { Variable }\end{array}$ & $\begin{array}{l}\text { Wskaźniki/ } \\
\text { Indicators }\end{array}$ & $\bar{x}$ & SD & $p^{*}$ \\
\hline \multirow{2}{*}{ Płeć/Gender } & Kobieta/Female & 90,30 & 24,96 & \multirow{2}{*}{0,361} \\
\hline & Mężczyzna/Male & 97,11 & 17,50 & \\
\hline \multirow{3}{*}{$\begin{array}{l}\text { Miejsce } \\
\text { zamieszka- } \\
\text { nia/Place of } \\
\text { residence }\end{array}$} & & 102,56 & 18,79 & \multirow{3}{*}{$<0,001$} \\
\hline & Wieś/Village & $05 ?$ & ? & \\
\hline & & $00, \cup 4$ & $2<, 09$ & \\
\hline \multirow{3}{*}{$\begin{array}{l}\text { Wykształcenie/ } \\
\text { Education }\end{array}$} & $\begin{array}{l}\text { Średnie, podstawowe } \\
\text { lub zawodowe/Secon- }\end{array}$ & 99,14 & 20,31 & \multirow[b]{3}{*}{$<0,001$} \\
\hline & dary, elementary or & & & \\
\hline & $\begin{array}{c}\text { vocational } \\
\text { Wyższe/Higher edu- } \\
\text { cation }\end{array}$ & 85,09 & 23,19 & \\
\hline \multirow{2}{*}{$\begin{array}{l}\text { Stan cywilny/ } \\
\text { Marital status }\end{array}$} & Wolny/Single & 88,49 & 24,11 & \multirow[b]{2}{*}{0,129} \\
\hline & $\begin{array}{l}\text { W związku małżeń- } \\
\text { skim/Married }\end{array}$ & 96,92 & 20,59 & \\
\hline \multirow{2}{*}{$\begin{array}{l}\text { Status } \\
\text { zawodowy/ } \\
\text { Professional } \\
\text { status }\end{array}$} & Aktywny zawodowo/ & 89,08 & 24,57 & \multirow[b]{2}{*}{0,120} \\
\hline & $\begin{array}{c}\text { Professionally active } \\
\text { Nieaktywny zawodowo/ } \\
\text { Professionally inactive }\end{array}$ & 96,09 & 20,50 & \\
\hline
\end{tabular}

$\bar{x}$ - średnia arytmetyczna/mean, SD - odchylenie standardowe/ standard deviation, $\mathrm{p}$ - wartość prawdopodobieństwa/probability value

* Test U Manna-Whitneya/Mann-Whitney U test

Źródło: opracowanie własne

Source: author's own analysis

Wykazano obecność istotnej statystycznie zależności pomiędzy stopniem religijności a wiekiem badanych osób ( $p=0,008)$. Zależność ta była dodatnia $(R=0,26)$. Oznacza to, że osoby starsze wykazywały się wyższą religijnością niż osoby młodsze.

Zachowania zdrowotne badanych osób związane były z poziomem ich wykształcenia $(p=0,006)$ oraz ze statusem zawodowym $(p=0,025)$. Wykazano, że wyższy poziom zachowań zdrowotnych prezentowały osoby z wykształceniem wyższym w porównaniu do osób z wykształceniem średnim, podstawowym i zawodo- 
wym oraz osoby aktywne zawodowo w porównaniu do osób niepracujących. Zachowania zdrowotne badanych osób nie były zależne od ich płci, miejsca zamieszkania czy stanu cywilnego (Tabela 3).

Tabela 3. Ocena zachowań zdrowotnych badanych w zależności od wybranych zmiennych socjodemograficznych

Table 3. Assessment of health behaviours depending on selected sociodemographic variables in a group of respondents

\begin{tabular}{|c|c|c|c|c|}
\hline $\begin{array}{l}\text { Zmienna/ } \\
\text { Variable }\end{array}$ & $\begin{array}{l}\text { Wskaźniki/ } \\
\text { Indicators }\end{array}$ & $\bar{x}$ & $\mathrm{SD}$ & $p$ \\
\hline \multirow{2}{*}{ Płeć/Gender } & Kobieta/Female & 61,68 & 8,25 & \multirow{2}{*}{0,797} \\
\hline & Mężczyzna/Male & 62,42 & 6,28 & \\
\hline \multirow{2}{*}{$\begin{array}{l}\text { Miejsce zamiesz- } \\
\text { kania/Place of } \\
\text { residence }\end{array}$} & Wieś/Village & 62,62 & 6,48 & \multirow[b]{2}{*}{0,565} \\
\hline & Miasto/Town & 61,44 & 8,32 & \\
\hline \multirow[b]{2}{*}{$\begin{array}{l}\text { Wykształcenie/ } \\
\text { Education }\end{array}$} & Średnie, podstawowe i & 60,25 & 7,20 & \multirow[b]{2}{*}{0,006} \\
\hline & $\begin{array}{c}\text { zawodowe/ } \\
\text { Secondary, elementary or } \\
\text { vocational } \\
\text { Wyższe/Higher education }\end{array}$ & 64,02 & 7,56 & \\
\hline \multirow{2}{*}{$\begin{array}{l}\text { Stan cywilny/ } \\
\text { Marital status }\end{array}$} & Wolny/Single & 61,00 & 7,91 & \multirow[b]{2}{*}{0,184} \\
\hline & $\begin{array}{c}\text { W związku małżeńskim/ } \\
\text { Married }\end{array}$ & 62,87 & 7,18 & \\
\hline \multirow{2}{*}{$\begin{array}{l}\text { Status zawodo- } \\
\text { wy/Professional } \\
\text { status }\end{array}$} & $\begin{array}{l}\text { Aktywny zawodowo/Pro- } \\
\text { fessionally active }\end{array}$ & 63,18 & 8,41 & \multirow{2}{*}{0,025} \\
\hline & $\begin{array}{l}\text { Nieaktywny zawodowo/ } \\
\text { Professionally inactive }\end{array}$ & 60,85 & 6,62 & \\
\hline
\end{tabular}

$\bar{x}$ - średnia arytmetyczna/mean, SD - odchylenie standardowe/standard deviation, $\mathrm{p}$ - wartość prawdopodobieństwa/probability value

* Test U Manna-Whitneya/Mann-Whitney U test

Źródło: opracowanie własne

Source: author's own analysis

Nie stwierdzono zależności pomiędzy wiekiem badanych a poziomem ich zachowań zdrowotnych $(R=0,18 ; p=0,074)$, choć zależność ta była bliska progu istotności. Dodatnia wartość korelacji sugerowała wyższy poziom zachowań zdrowotnych wśród osób starszych. Wykazano, że osoby częściej uczestniczące w mszach świętych odbywających się w niedzielę, a także częściej modlące się indywidualnie (kolejno $p=0,004$ oraz $p=0,048$ ) rzadziej były hospitalizowane z powodu depresji w ciągu ostatniego roku poprzedzającego badanie. Na progu istotności statystycznej znajdowała się także zależność pomiędzy częstością przyjmowania Komunii Świętej a częstością hospitalizacji. Zależność ta także była ujemna, osoby częściej przyjmujące Komunię rzadziej były hospitalizowane $(p=0,050)$. Wpływ praktyk religijnych na przebieg choroby był zatem zauważalny (Tabela 4).

Należy zaznaczyć, iż zachowania zdrowotne badanych pacjentów nie wpływały w sposób istotny statystycznie na ilość odbywanych przez nich hospitalizacji w ciągu ostatniego roku poprzedzającego badanie $(r=-0,03 ; p=0,799)$.
Tabela 4. Stopień religijności badanych i podejmowane praktyki religijne a częstość hospitalizacji z powodu depresji

Table 4. Degree of religiousness, undertaken religious practices and the frequency of hospitalizations due to depression in a group of respondents

\begin{tabular}{lcc}
\hline \multicolumn{1}{c}{ Zmienne/Variables } & $\mathrm{r}$ & $\mathrm{p}$ \\
\hline $\begin{array}{l}\text { Stopień religijności a częstość hospitalizacji/ } \\
\text { Degree of religiosity and the frequency of hospi- } \\
\text { talization }\end{array}$ & $-0,05$ & 0,636 \\
$\begin{array}{l}\text { Częstość uczestniczenia w mszach niedzielnych } \\
\text { a częstość hospitalizacji/ }\end{array}$ & $-0,28$ & 0,004 \\
$\begin{array}{l}\text { Frequency of attending Sunday Masses and the } \\
\text { frequency of hospitalizations }\end{array}$ & & \\
$\begin{array}{l}\text { Częstość uczestniczenia w mszach w dni powsze- } \\
\text { dnie a częstość hospitalizacji/ }\end{array}$ & $-0,14$ & 0,149 \\
$\begin{array}{l}\text { Frequency of attending Masses on weekdays and } \\
\text { the frequency of hospitalization }\end{array}$ & & \\
$\begin{array}{l}\text { Częstość przystępowania do Spowiedzi Świętej } \\
\text { a częstość hospitalizacji/ }\end{array}$ & & \\
$\begin{array}{l}\text { Frequency of going to Confession and the frequen- } \\
\text { cy of hospitalization }\end{array}$ & $-0,09$ & 0,380 \\
$\begin{array}{l}\text { Częstość przyjmowania Komunii Świętej a częstość } \\
\text { hospitalizacji/ }\end{array}$ & & \\
$\begin{array}{l}\text { Frequency of receiving Holy Communion and the } \\
\text { frequency of hospitalization }\end{array}$ & $-0,19$ & 0,050 \\
$\begin{array}{l}\text { Częstość modlenia się indywidualnie a częstość } \\
\text { hospitalizacji/ } \\
\text { Frequency of praying individually and the frequency } \\
\text { of hospitalization }\end{array}$ & $-0,19$ & 0,048 \\
\hline
\end{tabular}

$r$ - wartość korelacji rang Spearmana/Spearman's rank correlation coefficient $\mathrm{p}$ - wartość prawdopodobieństwa/probability value

Źródło: opracowanie własne

Source: author's own analysis

\section{Dyskusja}

Religijność dla wielu osób jest nieodłącznym elementem życia. Nie jest to parametr łatwy do scharakteryzowania, a tym bardziej zmierzenia, dlatego też postrzega się religijność jako konstrukt teoretyczny. Psychologowie starają się skwantyfikować duchowość człowieka, biorąc pod uwagę prezentowane przez jednostkę wartości, takie jak: znajomość siebie, samorealizacja, otwartość, sprzeciw wobec zła, poszukiwanie sensu życia oraz postawy i przeżycia religijne [9]. Prowadzone są liczne badania mające na celu określenie wpływu religijności na zdrowie człowieka. Osoby silnie wierzące mogą być przekonane, że nad ich zdrowiem czuwa Siła Wyższa, dlatego też są mniej podatne na choroby. Analizując zachowania zalecane przez religię, takie jak np. dieta, unikanie używek, można dojść do wniosku, że to przez zachowania zdrowotne osób wierzących są oni mniej podatni na różnego rodzaju dolegliwości, zarówno natury fizycznej jak i psychicznej [6].

W wyniku przeprowadzonych badań ustalono, że grupa pacjentów z depresją cechowała się znacznym stopniem religijności, jednak religijność pacjentów nie miała wpływu na prezentowane przez nich zachowania zdrowotne. Wykazano również, że większą religijnością cechowały się osoby starsze, mieszkające na wsi oraz 
osoby z podstawowym, zawodowym i średnim wykształceniem. Z kolei pacjenci z wykształceniem wyższym oraz aktywni zawodowo cechowali się wyższym poziomem zachowań zdrowotnych. Ponadto wykazano korelację pomiędzy niektórymi z religijnych praktyk a stanem psychicznym pacjentów. Mianowicie osoby, które regularnie uczęszczały na msze święte, a także praktykowały indywidualną modlitwę w mniejszym stopniu były podatne na zaburzenia depresyjne. Nie wykazano natomiast korelacji pomiędzy podejmowanymi zachowaniami zdrowotnymi pacjentów z depresją a częstością hospitalizacji.

Pawlikowski i wsp. [6] wskazują, że wierzenia religijne mogą być źródłem wielu potencjalnie korzystnych zdrowotnie zachowań. Odbywanie wspólnych pielgrzymek, jako długotrwała forma aktywności ruchowej, ma zdecydowanie pozytywny wpływ na zdrowie, ponadto spędzanie czasu w społeczności o podobnym światopoglądzie ma korzystny wpływ na psychikę człowieka. Kolejnym zdecydowanie korzystnym zachowaniem zdrowotnym jest podejmowanie różnego rodzaju diet i postów. W zależności od religii i święta wierzący ograniczają spożywanie mięsa, wieprzowiny, a zwiększają spożycie pokarmów roślinnych. Autorzy wskazują również na rzadsze korzystanie z używek przez osoby wierzące [6]. W badaniu własnym wykazano, że przestrzeganie zasad zdrowego odżywiania również ma duże znaczenie dla badanej grupy - spożywanie warzyw i owoców uzyskało średnio 4,83 pkt. na 6 pkt. możliwych, natomiast unikanie spożycia cukrów prostych i skrobi 4,67 pkt. Wiele religii na świecie zaleca wstrzemięźliwość od tytoniu, alkoholu i narkotyków. Wykazano również, że modlitwa kontemplacyjna pozwala ograniczyć odczuwany stres i napięcie emocjonalne, a regularne uczestniczenie w obrzędach religijnych ma charakter wypoczynku, który pozwala zregenerować zarówno ciało jak i umysł [6].

Wiele badań dotyczących zależności pomiędzy religijnością i zdrowiem prowadzonych było na terenie Stanów Zjednoczonych. Z kolei badania europejskie sugerują pozytywny wpływ różnych form religijności na zmniejszone występowanie zaburzeń depresji, zmniejszoną śmiertelność czy też ogólne lepsze postrzeganie swojego zdrowia. Spośród analizowanych czynników religijności przynależność do danej organizacji zdaje się mieć największy wpływ na zdrowie, szczególnie na występowanie depresji $(\mathrm{OR}=0,80)$. Nie zaobserwowano natomiast znacznego wpływu indywidualnej modlitwy na poprawę stanu zdrowia [10]. Z kolei w badaniu własnym zaobserwowano zależność pomiędzy praktykowaniem indywidualnej modlitwy a częstością hospitalizacji z powodu depresji $(R=-0,19, p=0,048)$. Taką zależność wykazano również w przypadku uczestnictwa w niedzielnych mszach $(R=-0,28, p=0,004)$. Ist- nieje wiele mechanizmów tłumaczących lepsze zdrowie osób religijnych. Najważniejszymi z nich wydają się być większe wsparcie społeczne, ograniczone palenie tytoniu, większy optymizm, posiadanie sensu życia oraz lepszej samokontroli [10].

Badanie prowadzone przez Kestenbaum miało na celu ocenę skuteczności interwencji kapelana w paliatywnej opiece chorych na raka na poprawę ich kondycji fizycznej i psychicznej. W badaniu wzięło udział 31 pacjentów w zaawansowanym stadium choroby nowotworowej, którzy zostali poddani sesjom duchowym z kapelanem, trwających około 7 tygodni. Jako narzędzie badawcze wykorzystano m.in. skalę Brief RCOPE do oceny religijności pacjentów, a także skalę oceny depresji CES-D oraz lęku STAI-S. W wyniku przeprowadzonych badań ustalono, że sesje prowadzone z kapelanem miały pozytywny wpływ na stan chorego, szczególnie w kwestii psychicznego radzenia sobie z chorobą [11]. Jest to kolejne badanie potwierdzające korzystny wpływ religii na zdrowie i samopoczucie chorego.

Ronneberg i wsp. [12] oceniali ochronny wpływ religijności pacjentów na wystąpienie zaburzeń depresyjnych. Badanie to trwało 2 lata, miało charakter prospektywny i wzięło w nim udział 1992 pacjentów z depresją oraz 5740 bez depresji, o średnim wieku 68 lat. Do określenia nasilenia zaburzeń depresyjnych autorzy wykorzystali skalę CESD-8, natomiast do oceny religijności wykorzystano kwestionariusz Leave-Behind Questionnaire. Na podstawie przeprowadzonych badań ustalono, że religijność pacjentów zarówno chroniła przed depresją, jak i pomagała wyzdrowieć chorym pacjentom. Osoby, które nie cierpiały na depresję, rzadziej na nią zapadały po 2 latach, jeśli regularnie uczestniczyły w obrzędach religijnych, natomiast osoby z depresją wykazywały mniejsze nasilenie depresji w przypadku, gdy regularnie podejmowały indywidualną modlitwę. Ronneberg i wsp. [12] wywnioskowali, że zarówno społeczna jak i osobista forma religijności ma korzystny wpływ na zdrowie psychiczne pacjentów. Pacjenci z badania własnego chorowali na depresję średnio 8 lat, a każdy z nich był przynajmniej raz hospitalizowany $z$ tego powodu. Na podstawie niniejszego badania wykazano, że pacjenci cechujący się większą religijnością, tj. częstszym uczestnictwem w niedzielnych mszach, oraz praktykujących indywidualne modlitwy, rzadziej byli hospitalizowani z powodu depresji.

Religijność, a także związane z nią wsparcie społeczne może mieć wpływ na występowanie zaburzeń depresyjnych u ludzi. Vicente i wsp. [13] zbadali tę zależność, określając ilość środków przeciwdepresyjnych przyjmowanych przez osoby starsze. Badanie to miało charakter retrospektywny, dane zebrano z ostatnich 90 dni, a w badaniu wzięło udział 1606 starszych osób, 
zamieszkujących południowo-zachodni rejon Brazylii. Jako narzędzie badawcze wykorzystano autorski kwestionariusz zawierający pytania dotyczące podłoża demograficznego, stosowanych leków, odczuwanych objawów depresyjnych, uzyskiwanego wsparcia społecznego oraz uczestnictwa w obrzędach religijnych. $\mathrm{Na}$ podstawie przeprowadzonych badań ustalono, że osoby cechujące się wyższą religijnością stosowały znacząco mniej leków przeciwdepresyjnych w porównaniu do osób niereligijnych. Z drugiej strony, nie zaobserwowano istotnego wpływu wsparcia społecznego na ilość stosowanych leków przeciwdepresyjnych przez badaną grupę. Badacze wywnioskowali, że religia może stanowić istotny sposób radzenia sobie z problemami natury psychicznej w badanej grupie osób [13].

W świetle przeprowadzonych badań, a także dostępnej literatury w zakresie prowadzonych badań możliwe jest wnioskowanie, że religijność może mieć korzystny wpływ na zdrowie psychiczne pacjentów z depresją. Jednocześnie nie wykazano znaczącego wpływu zachowań zdrowotnych na częstotliwość hospitalizacji z powodu depresji badanej grupy pacjentów. Najprawdopodobniej osoby religijne rzeczywiście cechują się lepszym zdrowiem, podejmują wiele zachowań zdrowotnych, które mają korzystny wpływ na ich zdrowie. Jednak trudno jest rozgraniczyć izolowany wpływ samej religijności od innych czynników na podejmowane przez pacjentów z depresją zachowania zdrowotne. Konieczne jest prowadzenie dalszych badań w tym zakresie.

\section{Wnioski}

1. Zachowaniami zdrowotnymi najczęściej przestrzeganymi przez pacjentów z depresją było przyjmowanie leków zgodnie z zaleceniem lekarza, spożywanie warzyw i owoców oraz produktów bogatych w kwas omega-3.

2. Większość pacjentów z depresją deklarowała niezaangażowanie w życie wspólnoty parafialnej. Pacjenci z depresją cechowali się znacznym stopniem religijności, jednak nie miała ona wpływu na prezentowane przez nich zachowania zdrowotne.

3. Wyższym stopniem religijności cechowali się starsi pacjenci z depresją, mieszkający na wsi oraz posiadający średnie, podstawowe i zawodowe wykształcenie. Pacjentów z depresją z wykształceniem wyższym oraz aktywnych zawodowo cechował wyższy poziom zachowań zdrowotnych.

4. Niektóre z religijnych praktyk miały pozytywny wpływ na zdrowie psychiczne pacjentów z depresją.
5. Zachowania zdrowotne prezentowane przez pacjentów z depresją nie miały istotnego wpływu na częstość hospitalizacji z powodu depresji.

\section{Piśmiennictwo}

1. Religia Słownik Języka Polskiego, https://www.sjp.pwn.pl/ sjp/religia;2514825.html, (data dostępu: 5.01.2020).

2. Pawlikowski J, Sak J, Marczewski K. Religia a zdrowie - czy religia może sprzyjać trosce o zdrowie? Część 2 - religijność a zdrowie. Kardiol Dypl. 2009; 8(1): 87-94.

3. Hill P, Pargament K. Advances in the Conceptualization and Measurement of Religion and Spirituality. Am Psychol. 2003; 58(1): 64-74.

4. Socha PM. Przemiana w stronę teorii duchowości. Wyd. I. Zakład Wydawniczy NOMOS, Kraków 2014.

5. Woźniak B, Zawisza K, Brzyska M. Religia a zdrowie o zależności między zaangażowaniem religijnym a funkcjonowaniem ciała w starszym wieku. Studia Socjologiczne 2015; 2(217): 215-238.

6. Pawlikowski J, Marczewski K. Religia a zdrowie - czy religia może sprzyjać trosce o zdrowie? Część 1 - wartość zdrowia w wielkich religiach świata. Kardiol Dypl. 2008; 7(10): 96-103.

7. Deklaracja Helsińska Światowego Stowarzyszenia Lekarzy. Etyczne zasady prowadzenia badań medycznych z udziałem ludzi, http://praca.biol.uw.edu.pl/wp-content/ uploads/2013/06/Deklaracja Helsinska.pdf, (data dostępu: 01.02.2020).

8. Socha P. Skale religijności, https://www.researchgate.net/ publication/275035029_Skale_religijnosci, (data dostępu: 21.11.2018).

9. Heszen-Niejodek I, Gruszczyńska E. Wymiar duchowy człowieka, jego znaczenie w psychologii zdrowia i jego pomiar. Przegląd Psychologiczny 2004; 47(1): 15-31.

10. VanderWeele TJ. Religion and health in Europe: cultures, countries, context. Eur J Epidemiol. 2017; 32(10): 857-861.

11. Kestenbaum A. What Impact Do Chaplains Have? A Pilot Study of Spiritual AIM for Advanced Cancer Patients in Outpatient Palliative Care. J Pain Symptom Manage. 2017; 54(5): 707-714.

12. Ronneberg CR, Miller EA, Dugan E \& Porell F. The protective effects of religiosity on depression: A 2-year prospective study. Gerontologist 2016: 56(3): 421-431.

13. Vicente ART, Castro-Costa É, Firmo J de OA, Lima-Costa MF, \& Loyola Filho Al. de. Religiousness, social support and the use of antidepressants among the elderly: a populationbased study. Cien Saude Colet. 2018; 23(3): 963-971.

Artykuł przyjęty do redakcji: 11.02.2020.

Artykuł przyjęty do publikacji: 04.05.2020.

Źródło finansowania: Praca nie jest finansowana z żadnego źródła. Konflikt interesów: Autorzy deklarują brak konfliktu interesów.
Adres do korespondencji:
Anna Kurowska
ul. Michałowskiego 12
31-126 Kraków
e-mail: anna2.kurowska@uj.edu.pl
Pracownia Teorii i Podstaw Pielęgniarstwa, Instytut Pielęgniarstwa
i Położnictwa, Wydział Nauk o Zdrowiu, Uniwersytet Jagielloński Collegium Medicum w Krakowie 